IRSH 48 (2003), pp. 27-54 DOI: I0.10I7/So0208590020009I 3

(C) 2003 Internationaal Instituut voor Sociale Geschiedenis

\title{
Bolshevism, Stalinism, and Social Welfare (1917-1936)*
}

\author{
DORENACAROLI
}

SUMmary: This article examines the main characteristics of the reform of the Soviet social security system in the I920s and the early years of Stalinism. It uses an interdisciplinary approach to examine the development of the system from many angles: the beneficiaries, the political debates, and the methods used to finance it. The reforms introduced during this period show that the Soviet welfare system depended almost entirely on economic progress; in 1927, the only state-funded provision was for disabled war veterans. Hence, the welfare system was quite specific: it was used as a tool to promote the industrialization of the country, favouring the workers at the expense of the disabled and unemployed, who were forced to fall back on various self-help strategies, some legal, some illegal. The disabled and unemployed constituted the main social problem of the r 920 . Social legislation between I93 I and I932, under the shadow of the impact which the Great Depression was having on Soviet society, progressively excluded the disabled and unemployed from the welfare system. Thus the USSR attempted to solve the unemployment problem by means of social exclusion.

After the Revolution the Bolsheviks, following other European governments who had passed social security legislation and developed the mutual benefit system, ${ }^{\text {I }}$ promised to introduce social security for all workers so as

\footnotetext{
* I should like to thank the journal editors and anonymous referees for their very valuable assistance in the preparation of this article, which is the first fruits of a research project in progress at the Max-Planck-Institut für Geschichte, Göttingen.

I. In examining the history of the Soviet welfare state I have found studies of the birth of the welfare state in Germany and England are particularly useful: T.W. Mason, Sozialpolitik im Dritten Reich. Arbeiterklasse und Volksgemeinschaft (Opladen, I977); W.J. Mommsen (ed.), The Emergence of the Welfare State in Britain and Germany (1850-1950) (London, I98I); J. Alber, Vom Armenhaus zum Woblfahrtstaat. Analysen und Entwicklung der Sozialversicherung in Westeuropa (Frankfurt am Main, 1982); G.A. Ritter, Sozialversicherung in Deutschland und England. Entstehung und Grundzüge im Vergleich (Munich, 1983); M. van der Linden (ed.), Social Security Mutualism: The Comparative History of Mutual Benefit Societies (Bern, 1996), pp. I I-38; Un siècle de protection sociale en Europe. Colloque tenu au Sénat les 24, 25, 26 octobre I996 à l'occasion du cinquantenaire de la Sécurité Sociale, Paris: Association pour l'Etude de l'bistoire de la sécurité sociale, 200 I (Paris, 200I).
} 
to "permanently safeguard the lives of each and every person, help them and improve their lot". ${ }^{2}$ But this "art of good government" did not produce a comprehensive welfare scheme for all workers, but only one for workers who were making the biggest contribution to industrializing a backward country prostrated by the experiences of the First World War. In this article I shall examine these reforms from various angles - the social groups for which they were designed, the actual welfare provision, and the way the social insurance funds operated from the October Revolution to I936 - based on official sources, including legislation, political speeches, and reports by social insurance funds.

There are several possible approaches to this, surely one of the most neglected aspects of Soviet history. One is the interdisciplinary method which I have previously applied to the study of welfare provision for abandoned and delinquent adolescents in the USSR in the 1920s. ${ }^{3}$ Another is micro-analysis, a current favourite with Russian historians seeking the reality of daily life in Stalinist Russia, so long obscured by the paradigms of Marxist historiography. The former approach works well for the function of social legislation and the architecture of both central and local social welfare institutions (Central Office and the regional welfare offices on the one hand, the social insurance funds on the other), but it does not give a clear picture of how social welfare affected living standards in the social classes, groups, and individuals which constituted any one Soviet enterprise, city or region: this can only be done by studying the micromechanisms which regulated the relationship between individual claimants and the insurance funds. While the two approaches are not mutually exclusive, in this article I have preferred the first in order to approach the history of the welfare system with a focus on the very idiosyncratic way it was financed: quite differently from other European welfare systems because, while some attempts were made to centralize a (very small) proportion of the available insurance funds, they were never regulated by a single central apparatus for the provision and fair distribution of resources according to the needs of each region. Because it was not financed by the state, the system was postulated on "chronic indebtedness": firms never paid their full welfare contributions, and so the welfare institutions themselves were chronically indebted to those they were trying to help.

My preliminary results, presented here, reveal the total inappropriateness of the word "system" to describe the nexus of institutions involved in managing social security, and of the word "reform" to describe the changes

2. M. Foucault, “'Omnes et singulatim': vers une critique de la raison politique”, in D. Denfert and F. Ewald (eds), Dits et écrits (1954-1988), 4 vols (Paris, I994), vol. 4 (1980-1988), pp. I34I6I, I44.

3. D. Caroli, La génération des "bommes nouveaux": abandon et délinquence juvénile en URSS (1917-1935) (Paris, 2003). 
introduced in the I920s. They show how little impact the welfare provision had on the daily life of people in all classes of Soviet society, forced to adopt any survival strategy, whether legal or illegal, to provide for their families. ${ }^{4}$ In part I of this article I shall examine the social insurance reforms between the October Revolution and the famine of summer I92 I. In part 2 I shall look at the series of welfare reforms between 1922 and I927, of which the aim was first to set up regional insurance funds and distribute those funds at local (provincial and district) level; secondly, to rationalize the distribution in proportion to welfare provision at provincial and district level; thirdly, to channel funds from the centre to those insurance funds that were in deficit. Finally, in part 3 I shall examine the reform of the insurance funds from I93 I to I933, which aimed, first, to provide specific funds for different branches of industry, and secondly, to transfer the management of social welfare from the People's Commissariat of Labour to the trade unions - turning welfare provision into a kind of privilege reserved for the most productive workers.

These incessant attempts at reform reveal how social legislation, instead of enhancing the "common weal" of the new society, was harnessed to foster the economic development of the country, giving the entire regulatory system a very precise function. ${ }^{5}$ This opens a fresh perspective on the discriminatory nature of a system which governed individuals according to their productiveness, rather than managing the social risks against which such individuals were supposed to be protected. ${ }^{6}$ This transformation in the nature of social protection, which intensified in the early years of Stalinism, draws attention to the economic constraints which restricted social welfare programmes. Research into social protection in Nazi Germany, where again welfare provision was progressively curtailed, has revealed the catastrophic impact of the Great Depression.7 This may provide a new key to the interpretation of the Soviet system, which may not only help to explain why the grandiose projects of the Revolution

4. On ways of doing this see L. Fontaine and J. Schlumbohm, "Household Strategies for Survival: An Introduction", in idem (eds), Household Strategies for Survival I600-2000: Fission, Faction and Cooperation, International Review of Social History, Supplement 8 (2000), pp. I - I 7. 5. For this theory see G. Teubner, "The Transformation of Law in the Welfare State", in G. Teubner (ed.), Dilemmas of Law in the Welfare State (Berlin, I986), pp. 4-10.

6. See also comments in A. Hunt and G. Wickham (eds), Foucault and Law: Towards a Sociology of Law as Governance (London, I984), pp. 39-58.

7. M.-L. Recker, "Sozialpolitik im Dritten Reich", in H. Pohl (ed.), Staatliche, städtische, betriebliche und kirkliche Sozialpolitik vom Mittelalter bis zur Gegenwart. Referate der 13. Arbeitstagung der Gessellschaft für Sozial- und Wirtschaftsgeschichte vom 28. März bis I. April 1989 in Heidelberg (Stuttgart, 1991), pp. 245-267; C. Sachsse and F. Tennstedt, Der Woblfahrtstaat im Nationalsozialismus. Geschichte der Armenfürsorge in Deutschland (Stuttgart, 1992), pp. 8 I-97; D. Crew, Germans on Welfare: From Weimar to Hitler (Oxford, 1998), pp. I66-187. 
failed, but also shed some fresh light on the early years of Stalinism, showing that they were not merely a catalogue of violence in the management of both social problems and the regulation of conflicts, ${ }^{8}$ but also the culmination of an economic crisis which faced the Party with the terrifying prospect of succumbing to the onslaught of capital, and Soviet society with the abyss of poverty and widespread injustice. Official Soviet propaganda threw a veil over all this, so successfully that when Beatrice and Sidney Webb, prominent representatives of the international working-class movement, visited the USSR in 1932 they brought back tales of how social security was available to all, and how the state had invested enormous resources to improve the lives of workers fighting for communism: in exchange for their loyalty and contribution to the building of a new society, they received welfare that was denied to workers under capitalist regimes. It is interesting to note that the Webbs' notions of working-class welfare in the USSR strongly influenced Sir William Beveridge's famous report in 1942, which, while its implementation was steadily cut back in Britain, had a considerable impact on social security schemes in Europe after the Second World War.

\section{THE LAVISH PROMISES OF THE OCTOBER REVOLUTION: SOCIAL PROTECTION FOR ALL WORKERS (I9I7-I92I)}

To analyse the welfare system between I917 to I92 I we must look first at the prerevolutionary legislation which set up insurance funds on the Bismarckian model, then at the decrees issued by the Bolsheviks on 22 December 1917, 3I October 1918, and Is November 192i bearing on safety at work and general social welfare. Throughout this period, there were continual changes to the social categories actually covered, although the Revolution had raised hopes that communism would put bread in the mouths not only of the proletariat, but also of all those who had been ignored by pre-I9I7 governments: the disabled, women, and children who had been left destitute, dependent on the "charity" of others, or forced into vagrancy. However, the story really begins with the social insurance law voted by the Duma on 23 June I9I 2, which was substantially modified by a decree by the Provisional Government on 27 July 1917.

It is worth giving a brief account of the protection envisaged by the Duma, although owing to the Great War it had very little impact on the lives of working men and their families. It must be stressed that this law extended insurance to no more than 23 to 25 per cent of the blue- and white-collar workers in key branches of industry such as mining, metals,

8. S. Plaggenborg, "Stalinismus als Gewaltgeschichte", in idem (ed.), Stalinismus, Neue Forschungen und Konzepte (Berlin, I998), pp. 7I-I I 2. 
and urban and river transport - some 3 million out of a total of $\mathrm{i} 8$ million. It also introduced factory sick funds providing disability benefit for a period of I 2 weeks, after which the worker was entitled to welfare benefit provided by mutual insurance funds (strakhovye tovarishchestva). These health insurance mutuals, unlike their counterparts in other countries, did not cover medical expenses and were managed by the employers, who controlled two-thirds of the voting rights, whereas the workers themselves provided three-fifths of the finance against the employers' two-fifths. ${ }^{9}$ The 27 July I9I7 decree made some significant changes intended to stimulate the scheme, the development of which was being hampered by the War, although at I January I9I7 it comprised 2,025 health insurance funds with over I.5 million members. Accident insurance for workers was extended to I 3 weeks, and sickness benefit, at a level of two-thirds of wages or salary, was to run for 6 months instead of 4 ; maternity leave was increased from 6 months to 8 , with payment of one-quarter of wages for 20 weeks. The institutional focus was shifted from factory-based insurance funds (bol'nichnie kassy) to regional (city or district) funds managed by the votes of the workers themselves, although employers were to fund the scheme at a rate of 2 per cent of wages up to a limit of 18 roubles per year. $^{10}$

A full study of the role of skilled workers in the health insurance funds, their growing consciousness of their social rights, and the impending struggle between workers and employers for the control of labour would require a complete retrospect of the prerevolutionary welfare system. For our present purpose, however, it is sufficient to say that despite their revolutionary proclamations of universal social security, the Bolsheviks favoured the same branches of industry as the Russian government had done. The former reacted to the provisional government's 27 July i 9 i 7 law by promising social security to all workers, including those in small

9. N.A. Vigdorchik, Sotsial'noe strakhovanie v obshchedostupnom izlozhenii (Moscow, 1927), pp. I49-I58; L.V. Zalebin, Puti i sud'by sotsial'nogo strakhovaniia. Kratkii ocherk ekonomicheskikh osnov sotsial'nogo strakhovaniia (Moscow, 1929), p. 77. This law came in much later than its equivalents in other European countries (Germany I 883/I 884, France I 898, Italy I 886/ I 898, UK I 8 I I/ I 897), and was never implemented as far as workers in Siberia and Central Asia were concerned: V.L. Stepanov, "Die Sozialgesetzgebung Otto von Bismarcks und die russische Arbeiterversicherungsgesetze”, in D. Beyrau et al. (eds), Reformen im Russland des 19. und 20. Jabrhunderts. Westliche Modelle und russische Erfahrung (Frankfurt, I996), pp. I09-138; A. Semenov, "Mutual Benefit Societies in Russia", in Van der Linden, Social Security Mutualism, pp. 403-4I6; Istoriia predprinimatel'stva v Rossii, 2 vols (Moscow, 2000), vol. 2, pp. 404-437, 4I7-4I 8 .

I0. Vigdorchik, Sotsial'noe strakhovanie, pp. I49-158; B.Q. Madison, "The Organization of Labour Services", in C.E. Black (ed.), The Transformation of Russian Society: Aspects of Social Change since I86I (Cambridge, I960), pp. 515-540; idem, Social Welfare in the Soviet Union (Stanford, CA, I968), pp. 50-57. 
businesses, construction, and handicrafts. ${ }^{\mathrm{II}}$ On 30 October I9I7 the People's Commissariat of Labour (Narkomtrud) announced universal accident and sickness benefit, healthcare, extended maternity leave, unemployment and disability benefits, and widows' pensions for all industrial and agricultural workers, financed solely by contributions from employers. But this universal provision, unsupported by any government finance, soon had to be cut back, because in the current economic climate employers were simply unable to pay the contributions. ${ }^{\mathrm{I2}}$

A crucial element here is the role of the "avant-garde" working class in the management of insurance funds in various branches of industry. It is crucial not only because it provides an insight into the persistence of classconsciousness $^{13}$ and the spread of the proletarian cultural values (comradely cooperation and the brotherhood of all workers) which were the bedrock of working-class solidarity, ${ }^{14}$ but also because in the 1920 s protection was extended not to the entire proletariat, but only to skilled workers. The 22 December I9I7 decree restricted sickness, disability, and maternity benefits, and medical treatment for the families of the insured, to wage-earners only. This decree envisaged larger payments, over a longer period, than the previous decree: full salary during sick leave, from Day I for six months, after which disability benefit was payable. Maternity leave was to be double that envisaged in the prerevolutionary decree: eight weeks before the birth and eight afterwards, with one-quarter of wages paid for nine months after the birth. The reorganization of health insurance funds on a regional (city or district) basis continued, and the regional authorities were also given responsibility for medical care. The funds were managed by workers' representatives and financed by the employers at a level of io per cent of payroll. ${ }^{\text {is }}$

However, this decree, which threatened to provoke a backlash among peasants who had fought in the Great War, or the civil war which had led

I I. This was the embodiment of the Leninist ideal of democratic self-government by the masses. See K. Anderson, Lenin, Hegel and Western Marxism (Urbana, IL, I 995), pp. I53-159. This ideal of self-government was fundamentally opposed to state socialism, whereby the economic forces of capitalism were centred in the state: see P. Schiera, Laboratorium der bürgerlichen Welt. Deutsche Eissenschaft im 19. Jahrbundert (Frankfurt am Main, 1992), pp. 174-210.

I2. Vigdorchik, Sotsial'noe strakhovanie, pp. I58-i62.

I 3. See e.g. L.H. Siegelbaum and R.G. Suny, "Class Backwards? In Search of a Soviet Working Class", in idem (eds), Making Workers Soviet: Power, Class and Identity (Ithaca, NY, [etc.], 1994), pp. I-26; S. Fitzpatrick, "Ascribing Class: The Construction of Social Identity in Soviet Russia”, in idem (ed.), Stalinism: New Directions (London [etc.], 2000), pp. 20-46.

I4. A concept developed before the Revolution by A.A. Bogdanov (1873-1928). See J. Scherrer, "Pour l'hégémonie culturelle du prolétariat: aux origines historiques du concept et de la vision de la 'culture prolétarienne", in M. Ferro and S. Fitzpatrick (eds), Culture et révolution (Paris, I989), pp. I I-23, I3-I4.

I5. Vigdorchik, Sotsial'noe strakhovanie, pp. I63-I64; V. Kuibyshev, "Tezisy o sotsial'nom strakhovanii (Utverzhdennye TsK RKP 4/IX/I922)”, Voprosy strakhovaniia, I (I922), pp. 6-8. 
to the victory of the Revolution, was modified on 3I October I9I 8 to bring peasants and artisans back under the social security umbrella. The new decree abolished "capitalist insurance" (kapitalisticheskoe strakhovanie) in favour of socialist protection (socialisticheskoe obespechenie), and set up a five-tier sickness and accident benefit scheme, plus unemployment and maternity benefits, and healthcare and medical treatment in illness and childbirth. ${ }^{16}$ In theory, contributions from employers, cooperatives and private institutions were supposed to vary according to the level of risk, from 26 to 38 per cent of the wages (of which 6 per cent was earmarked for unemployment and maternity benefit). The health insurance funds were made responsible for managing these new benefits, which effectively turned them into social security funds and incorporated them into local social security and employment agencies (podotdely sotsial'nogo obespecheniia i okbrany truda) under the aegis of the Social Security and Labour Department of the People's Commissariat of Labour (Narkomtrud). Medical attention was provided either in factory outpatient clinics or in local health units. ${ }^{17}$

In the period of war communism (June I9I8-autumn 1920), when extensive nationalization took place, the health insurance funds were unable to help any more workers than had benefited before the Revolution, probably because they used the available resources to make "thousands of wooden arms and legs" for disabled soldiers - some 775,000 of them according to the statistics produced by Central Administration based on data gathered on I3 March I92I. Workers received only a miserable payment in kind which was not even enough to feed themselves and their families. ${ }^{18}$ From I9I9 onwards, low wages and indigence during periods of unemployment drove workers in Moscow and Tambov to survive by raising food and cutting firewood on farms (sovnarchozy) rented by their firms. ${ }^{19}$ If they fell sick they were urged to return to the factory as quickly as possible. As for the peasants, they received no assistance except in times of famine, and even then it took the form of a subsidy to their farm, gradated according to whether the sufferer was a "poor peasant" (krest'ianin bedniak), whose family would otherwise not have the "bare necessities", or a "moderately well-off peasant" (krest'ianin sredniak), whose family would receive no assistance unless he were conscripted. As in other European countries, peasant welfare was

I6. Vigdorchik, Sotsial'noe strakhovanie, pp. 165-169; Iu. V. Iakushev, Gosudarstvennoe strakhovanie v Rossii (Moscow, 1998), pp. 7-8, 42-49.

17. Vigdorchik, Sotsial'noe strakhovanie, p. I66.

18. Ibid., pp. I8I-19I.

19. M. Ferretti, "Révolution et vie quotidienne: le témoignage des correspondants ouvriers de la Pravda (1922)”, Le Mouvement Social, I90 (2000), pp. 6I-95, 73-76. Many German peasants also had allotments: J. Mooser, Arbeiterleben in Deutschland 1900-1970 (Frankfurt am Main, I984), pp. $85-86$. 
administered by rural authorities or commissions, which in 1920 were turned into mutual aid committees responsible for constituting reserve funds to pay for family income support, extra food rations, and support for agricultural workers. ${ }^{20}$

The change to a market economy, and the consequent reorganization of industry under the New Economic Policy launched on 2I March I92I, brought about no improvement: employers could pay only the most minimal insurance contributions. After the catastrophic famine of summer I92I, if not before, many firms tried to stimulate production by introducing piecework ${ }^{21}$ - causing a deterioration in working conditions - and putting fresh restrictions on the skill-based entitlement to temporary disability or unemployment benefit. This was only the first step towards restricting welfare provision; it was confirmed by a new decree on Is November I 92 I that represented a return to the status quo of 22 December I917, confining social security benefits to wage-earners and abandoning artisans, shopkeepers, servants, peasants, journeymen, and temporary workers to the tender mercies of the market economy. All benefits temporary disability, maternity, unemployment - were subjected to conditions relating not only to place of residence, but also to length of service and union membership. Disabled workers could claim benefits at an earlier stage, after eight years' service and after reaching the age of fifty. The unemployed were divided into two categories, skilled and unskilled; they had to register at their local labour exchange, and received benefits proportionate to their length of service and of union membership: nine months' membership gave entitlement to one-third to one-fifth of wages per nine to twelve months worked (one year's membership for blue-collar members, three years for non-members; three years for white-collar members and five years for non-members). Unemployed workers and their families were entitled to free medical care organized either locally or centrally. Maternity benefit was payable at full wage rate for sixteen weeks depending on type of work (eight weeks before the birth, eight weeks after), plus a grant for the baby (half of wages) and an allowance of oneeighth of monthly salary for breastfeeding. ${ }^{22}$

By this stage the two kinds of welfare provision were being managed by two different authorities: the factory insurance funds, which were responsible for health and safety at work, and the local social security offices, which dealt with disability and unemployment. Since the available

20. N. Miliutin, "Sotsial'noe obespechenie v usloviiakh novoi ekonomicheskoi politiki", Voprosy sotsial'nogo obespecheniia, 5-6 (1921), pp. I-I2, 7. The data were drawn from only I9 provinces (out of a total population of $86,319,000$, not counting the Ukraine). See A.N. Vinokurov, “Sotsial'noe obespechenie krest'ian”, Biulleten' Narodnogo Komissariata sotsial'nogo obespecheniia, I (I92I), pp. 8-I3.

21. Ferretti, "Révolution et vie quotidienne", pp. 66-67.

22. Vigdorchik, Sotsial'noe strakhovanie, p. I 84 . 
insurance funds were plainly inadequate, plans were afoot for a state Reserve Fund to cope with unforeseen natural disasters (epidemics, famine), while the provinces with the highest rates of disability (either temporary, due to accidents at work, or permanent, due to war wounds) and unemployment would be entitled to demand additional contributions from employers. ${ }^{23} \mathrm{~A}$ few years later these proposals were embodied in a reform of the insurance funds - probably because the terrible famine of I $92 \mathrm{I}$, in which five million people died, showed the need for a reserve to cope with emergencies. ${ }^{24}$

\section{THE "CHRONIC INDEBTEDNESS" OF THE CENTRAL AND LOCAL INSURANCE FUNDS ( I 9222 - I 927 )}

The reforms between 1922 and 1927 focused mainly on supporting the Soviet Union's industrial development, rather than on introducing a welfare system intended to foster overall social cohesion. This meant that the number of workers under the welfare umbrella increased by about a million annually from 1922, but it was at the expense of the disabled and the unemployed; in the I920s at least, the former group were rated as "class I" beneficiaries because they received more generous payments than the latter group. This was, however, a political decision which seemed to ignore the fact that the shortage of money in local funds was occurring not downstream but upstream: i.e. the problem was not the distribution of available funds, but essentially the fact that, owing to the acute economic crisis, employers were unable to pay their welfare contributions, and therefore the funds were "chronically indebted" to their clients. To clarify the workings of this welfare system, which was subject to continual changes, I shall discuss the three legislative reforms in relation to four points: the social attitudes of the insurance funds; the social problems of disability and unemployment; the Marxist debate over unemployment; and the transfers of bank deposits from the central insurance fund.

The first reform, launched by decree on I December i922, set up two kinds of fund: various local industrial funds (raionnye, obshchegorodskie, okruzhnye, and uezdnye kassy), serving 2,000 persons within a radius of two versts (c. $2,150 \mathrm{~km}$ ), and transport funds set up by the rail and river transport unions. The industrial funds were managed by the provincial funds (gub/obl/strakbkassy); the transport funds by a Central Transport Fund controlled by the Central Social Insurance Administration

23. Miliutin, "Sotsial'noe obespechenie", pp. 6-7; I.L. Baevskii, Praktika sotsial'nogo strakhovaniia v SSSR (Moscow, 1926), pp. 29-35.

24. In fact, the assistance which kept more than io million people alive came from abroad, particularly from the United States: M. Wehner, "Golod I92 I-I 922 gg. v Samarskoj gubernii i reakcija sovetskogo pravitel'stva”, Cabiers du Monde Russe, 38, I-2 (January-June 1997), pp. $223-242$. 
(Tsustrakh). Each republic had a main Regional Social Security Office (Glavsotsstrakh) responsible to the Central Social Insurance Administration (Tsustrakh) which was part of the People's Commissariat of Labour. ${ }^{25}$ In 1923 two decrees were issued, regulating the types of welfare contributions payable by employers and prohibiting the misdirection of funds. The first of these decrees (I 2 April 1923) established a four-tier contribution system geared to the level of risk in the work involved. ${ }^{26}$ The second (I 4 June 1923) evoked the need for greater flexibility in the use of provincial funds for the disabled and the unemployed, and set up four funds which were to be used only for their specified purpose. Fund B, the permanent disability fund (including the death of a breadwinner), and fund $\mathrm{C}$, the unemployment fund, were managed by the provincial insurance funds (gubsotsstrakhi). Fund A, covering temporary disability and various welfare benefits, and fund D, for medical care, were managed by the social security funds and the local health authorities, respectively. ${ }^{27}$

This reallocation of the funds' responsibilities did nothing to solve the problems of the employers, who were paying only 30 to 40 per cent of the amounts required and were constantly reducing, indeed decimating, their contributions. In 1922 these fell from 2 I to 28 per cent of wages to I 4 to $2 \mathrm{I}$ per cent; in 1923 , to Io per cent: consequently only ro to 20 per cent of workers (4.5 million) enjoyed any form of social security in 1923. Moreover, there were great discrepancies between the performances of different insurance funds: whereas the provincial funds were paying only very small sums ( 10 to I 3 roubles for the disabled, 6 to 8 roubles for I 5 per cent of the registered unemployed), the district funds were more generous because disability benefits were equivalent to full salary from Day I, while maternity benefits were paid for 4 months ( 2 months before the birth, 2 after) - and the 4 months could be stretched to 9 , thanks to the 3 roubles paid for the baby. ${ }^{28}$

To solve the crisis in the provincial funds, V. Shmidt, the People's Commissar for Labour, proposed two solutions at the Eleventh Congress of Soviets in 1923, neither of which solved the problem of employers' inability to pay their insurance contributions. First, he suggested that contributions should be extorted by force; secondly, he suggested reducing the numbers of unemployed by retaining young workers and putting the older ones on to workfare. Payments were indeed extorted by force, ${ }^{29}$ but neither this nor the establishment of a fixed quota for adolescents and

25. Baevskii, Praktika sotsial'nogo strakhovaniia, pp. 30-3 I.

26. Iakushev, Gosudarstvennoe strakhovanie v Rossii, pp. 58-59.

27. Baevskii, Praktika sotsial'nogo strakhovaniia, pp. 325-326.

28. "Sotsial'noe strakhovanie na XI Vserossiiskom S'ezde sovetov. Iz doklada NKT tov. Shmidta", Voprosy strakhovaniia, 3-4 (1924), pp. 9-I2.

29. "Beznadezhnye dolgi nesostoiatel'nykh dolzhnikov", Voprosy strakhovaniia, 23 (I924), pp. $4-7$. 
young people succeeded in solving the problem, because it was a vicious circle created by the fact that the provision of welfare benefits depended directly on the employers. Forced payments did nothing to stimulate productivity; firms that were in arrears, or were unproductive, were faced with imminent bankruptcy. The second measure could not solve the unemployment problem because its root causes were the surplus of unskilled seasonal agricultural workers, and the lack of skills among the immediate postwar generation..$^{\circ}$

A good example to illustrate the workings of the insurance funds, whose activities were typically intermittent owing to employers' inability to pay welfare contributions, the extent of local disbursements, and the serious incidence of sickness and disability they were expected to cope with, is provided by the Moscow fund over a few months in 1923 and I924. In October I 923 only 53.5 per cent of contributions had been paid, whereas in July 1924 it was 93.7 per cent. But the increased contributions did not lead to increased payouts, owing to a 3.5 per cent increase in expenditure on unemployment and sickness benefit and pensions: the number of recipients increased from 361,000 in September 1923 to I,252,000 in July I 924 (assuming an average annual payout of 36.5 roubles per person). As a result, the fund was in deficit for 3 months in both 1923 and 1924 , and during that time no benefits were paid at all. ${ }^{3 \mathrm{I}}$ As happened again subsequently, the local authorities, faced with the prospect of empty coffers, refused to pay any contributions to Central Administration (which could then have channelled the money towards the neediest provinces, i.e. the industrialized ones), ${ }^{32}$ and instead paid them direct to the regional office, which used them almost exclusively at local level. This tendency to spend funds locally was a general one. In response, the Head of Social Security Administration, B. Faingol'd, and L. Nemchenko, the union representative, agreed that regional office funds should be treated as a "common pot" from which contributions could be channelled towards the poorest districts, and declared that local officials must be educated into the conviction that

[...] the financial system of Soviet social insurance did not recognize the existence of "local" insurance funds as such; the money belonged to the insurance Reserve Fund and must be disbursed according to the needs of working people as a whole and not just those of "our own folk" - in Archangel, Siberia or wherever. ${ }^{33}$

30. S. Fitzpatrick, Education and Social Mobility in the Soviet Union, I92 I-I934 (Cambridge, 1979), pp. 47-48, 54-55, 59-60, 199-203, 225-226.

31. V. Beleliubskii, "Obshchie godovye rezul'taty finansovykh operatsii leningradskikh strakhovykh uchrezhdenii”, Voprosy strakhovaniia, 23 (1922), pp. I2-I3.

32. B. Faingol'd, "Tsentralizatsiia vnimaniia i prikhoda - detsentralizatsiia kontrolia i raskhoda", Voprosy strakhovaniia, 9 (1923), pp. 3-5.

33. N. Bykhovskii, "Novoe polozhenie o fondakh i zadachi strakhorganov", Voprosy strakhovaniia, 48 (1924), pp. 4-7, 7. 
Furthermore, they said, what was being done in Moscow could not be done in all the other provinces, not only because it contravened the principle just announced, but also because if inpayments were decentralized, local insurance funds would acquire much greater power over employers. ${ }^{34}$

It is hard to tell how far the tendency to spend funds locally reflected resistance to centralized distribution on the part of local officials. More probably it was a "local custom" which arose in response to the gravity of the unemployment problem: by the end of 1923 the number of registered unemployed had passed the million mark. ${ }^{35}$ Assuming that central government was not going to take over the management of the unemployment problem, a fresh set of measures had to be envisaged, and this led to another reform and to a debate over social security ending in the defeat of the Marxist view. Two tendencies emerged, one represented by B. Faingol'd, the head of social security administration, and other by two Marxist theorists, N.A. Vigdorchik and A. Zalebin. Faingol'd, knowing how limited were the resources of the local social security funds, suggested limiting welfare provision to productive wage-earners excluding most of the unemployed. ${ }^{36} \mathrm{He}$ criticized the "do-gooder" attitude of Vigdorchik, who argued that social insurance, and particularly unemployment benefit, should guarantee that everyone had "enough to live on". Zalebin, preferring the term "social protection", stressed that it should guarantee a living wage for a million indigent workers and their families, of all nationalities, and be financed by entrepreneurs through direct taxes. ${ }^{37}$

The provisions subsequently instituted actually differentiated even among those million unemployed. The second reform reorganized not only local but also central institutions and made local payments compulsory. Basically, it merged the two types of local insurance, aiming at a more flexible use of local funds in view of the fact that the disabled and the unemployed constituted a mobile group. ${ }^{38}$ In accordance with the Is January 1924 decree, the first three funds (A, B and C), which had been separated by the previous decree, were remerged into a single pensions and benefits fund which could be used flexibly to meet local needs. In all there

34. Faingol'd, "Tsentralizatsiia vnimaniia i prikhoda", pp. 3-5.

35. Ferretti, "Révolution et vie quotidiennne", pp. 67-68.

36. B. Faingol'd, "Eshche o teoreticheskikh osnovakh sotsial'nogo strakhovaniia”, Voprosy strakhovaniia, 32-33 (1924), pp. I65-166.

37. A. Zalebin, Teoriia sotsial'nogo obespecheniia (Moscow, I924), pp. I 59, I83, I99.

38. M.M. Landis, "Sotsial'noe strakhovanie v SSSR", Sotsial'naia gigiena, 3-4 (1929), pp. 40-53,

47. This reform, which merged two formerly separate welfare systems (insurance and pensions), was abandoned two years later. It was subsequently reintroduced and persisted up to the end of the 1980 . While the flexible use of funds was a plus, it did not help prevent accidents at work, because employers strove to increase the privileges of their own workers. See V. Kulikova (ed.), Smeshannaia ekonomika: formirovanie i upravlenie (Moscow, 1994), pp. 209-2 I 2. 
were five funds; although they are an important aspect of the formation of the Soviet state, their full history has yet to be written. Fund (A) was the local pensions and benefits fund, (B) the local healthcare fund, (C) the provincial fund, (D) the All-Russian social insurance fund, and (E) the republican medical treatment reserve fund. ${ }^{39}$ Incoming contributions were to be channelled into two funds: (I) pensions and benefits, (2) healthcare, the proportions depending on the size of the payment ( 16 to I 8 per cent of salary, or Io to I 2 per cent for reduced contributions). The regional fund was required to pay io per cent of each fund to the higher authorities Central Administration and the People's Commissariat of Health. These payments were used to create two independent central funds in each of the Soviet republics, which were empowered to redistribute available funds to needy local funds: the USSR Reserve Fund (Vsesoinznii Zapasnii Fond) and the Republican Healthcare Fund (Respublikanskii Fond Lechpomoshchi). $4^{\circ}$ Official statistics showed that the number of employers paying contributions had risen to 80 per cent in I924, and the service had generally improved. More people were receiving benefit (almost 5.5 million); 700,000 disabled were receiving I 2 to I 8 roubles; the temporary disability benefit was increased to soo per cent of wages; and more skilled workers $(200,000)$ were even receiving holiday pay.

However, an analysis of contributions from heavy industry and transport aroused fears that this improvement might be shortlived. From 1924 onwards, despite the introduction of a four-tier contributions structure (from I 6 to 22 per cent), contributions dropped by I 4 per cent, to $\mathrm{I} 2$ per cent for transport and Io per cent for the mining, metal and electrical industries, especially in the regions of Nizhnii-Novgorod, the Urals, Donbass, and Briansk, which suffered from is to 20 per cent "chronic indebtedness" to the insurance funds. Although the Union had vetoed a reduction of contribution rates in heavy industry from I 5.6 per cent to I 4 per cent of wages, in fact the employers were unable to pay more than Io to I 2 per cent, and those in the transport industry more than is per cent. The situation was worst in the most heavily industrialized areas, particularly the Ukraine, where the insurance funds needed cash injections from outside to balance their books.

In response, a plan was made involving two "special" provisions which reveal a marked and increasing "totalitarian" trend in social legislation: welfare was wholly subordinated to the needs of industrialization. At the Sixth Trade Union Congress in I924, Nemchenko proposed that social insurance funds in the industrialized areas should be supported by the nonindustrialized areas. This meant that the regional offices of the republics would transfer funds from the nonindustrialized provinces to

39. Baevskii, Praktika sotsial'nogo strakhovaniia, p. 326.

40. Ibid., pp. I80-I8 I. 
the industrialized ones mentioned above. Moreover, the regional offices would also be required to set up republican funds to receive local contributions for use in the indebted republics. ${ }^{4 \mathrm{I}} \mathrm{A}$ rough calculation showed that Central Administration would have to draw on the Reserve Fund to make good the deficits not only in the local funds $(600,000$ insured members), but also in the transport funds (800,000 insured)..$^{42}$ The balance in the Reserve Fund was calculated, more or less realistically, by assuming that about 5.5 million insured paid 35 roubles per year each, producing a total balance of $23 \mathrm{I}$ billion (less $3 \mathrm{I}$ billion chronic debt). This would leave a surplus of about 22 billion ( 20 billion from 10 per cent of local funds plus 2 billion from transport funds). However, owing to a deficit of 6.5 to 7 billion roubles in the transport funds, which swallowed 60 per cent of the budget of the Reserve Fund ( 10 to I 2 billion), the Fund had only 5 billion roubles left for local distribution. Fearing that not even this 5 billion could be collected, in which case the plan to extend preventive healthcare would fail, Central Administration and the regional offices were advised to take legal action against officials who used funds solely at local level, even if their executive committees had pressured them into it. 43 The result was a second measure: in 1925 a Supreme Council (Vysshii Soviet) was set up to direct and supervise the local funds. It comprised four trade-union representatives and two from the Council for the Economy, the Transport Council and the People's Commissariat of Finance. ${ }^{44}$

Under this guidance, payments from the local insurance funds were expected to be better managed. But, strangely enough, the aim of this guidance was not to divert large amounts of money into the Reserve Fund to meet the needs of heavy industry and transport. A speech by L.B. Kamenev at a meeting of the Moscow Communist Party in 1925 indicates that social security funds were to be considered as a "long-term loans" for the reconstruction of industry, because that task "could not be accomplished unless state channels are used to collect all the funds now scattered among different organizations". 45 So in I 925 the Council of People's Commissars (Sovnarkom) resolved to transfer all social security funds from the Bank of Industry and Trade (Prombank) and the All-Russian CoOperative Bank (Vsekobank) into the State Bank (Gosbank). But this transfer of control, the justification for which was that the development of industry - re-equipment, electrification, setting up new industries -

4I. L. Nemchenko, "Plan i perspektivy sotsial'nogo strakhovaniia”, Voprosy strakhovaniia, 44 (1924), pp. 6-8.

42. N. Bykhovskii, "Novoe polozhenie o fondakh i zadachi strakhorganov", Voprosy strakhovaniia, 48 (1924), pp. 4-7.

43. Ibid., p. 7.

44. "Vysshii Strakhovoi Sovet sil'no pomozhet delu sotsstrakha", Voprosy strakhovaniia, 48 (1924), p. 3 .

45. "Sotsstrakh i Gosbank", Voprosy strakhovaniia, 39 (1925), pp. 3-4. 
would in itself stimulate improvements in social insurance, did not improve the situation of the central fund: instead, it abolished a number of advantages such as the covering of employers' debts, free fund management and loans to social services. ${ }^{46}$ In the Ukraine, the transfer of funds from Prombank and the Bank of the Ukraine to the State Bank put an end to the modest loans previously offered, reducing the social insurance funds' budget by 900,000 roubles. ${ }^{47}$

These measures explain why the funds intended for the unemployed who were not contributing to industrialization - were constantly being reduced. By mid-I924 the number of unemployed had reached I,200,000. Although only 300,000 of them received an average of 9 roubles per month (25 per cent of wages), in July Faingol'd introduced two more or less authoritarian measures intended to reduce that number still further. First, he "purged" 60 per cent of the names on the list of registered unemployed..$^{8}$ Secondly, he introduced a rule compelling applicants for unemployment benefit to register at the exchange (before I May i925) within three months of losing their jobs, "first, because [this] is the longest that a worker or clerk can live on his savings, and secondly, because this is the period of time during which rural labourers usually return to the countryside to do agricultural work after their dismissal". ${ }^{49}$ The dire shortage of cash in the insurance funds also raised the question of what kind of assistance the unemployed should receive: benefits in kind (canteens, boarding houses, as in previous years) or cash? In I925 Faingol'd, supported by numerous local officials, preferred cash because it would cost less than organizing benefits in kind, which were seen rather as a kind of social assistance to unskilled peasant migrants who were not entitled to unemployment benefit because "as their resources grow, the funds must focus their attention on tightening the welfare provision rules and broadening the range of recipients, rather than spending any substantial part of those resources on unemployed persons who were not previously insured". ${ }^{\circ}$

All this led directly to the third reform, which was intended to ensure a more efficient distribution of central funds - not in order to improve industrial working conditions, but in order to increase loans to employers.

\footnotetext{
46. Ibid., p. 4 .

47. V. Sher, "Ukraina defitsitna", Voprosy strakhovaniia, 23 (1926), p. I4.

48. V. Kuziatin, "Ocherednye voprosy strakhovaniia bezrabotitsy", Voprosy strakhovaniia, 4-5

(1925), pp. I0-I2. Further research reveals other examples of the violence inflicted on claimants:

D. Crew, "Gewalt 'auf dem Amt'. Wohlfahrtsbehörden und ihre Klienten in der Weimarer Republik", in T. Lindenberger and A. Lüdtke (eds), Physische Gewalt. Studien zur Geschichte der Neuzeit (Frankfurt am Main, 1995), pp. 21 3-238.

49. Kuziatin, "Ocherednye voprosy strakhovaniia bezrabotitsy", p. I 2.

50. B. Faingol'd, "K voprosu ob organizatsii natural'noi pomoshchi bezrabotnitsy", Voprosy strakhovaniia, 50 (1925), pp. 3-4, 3 .
} 
A decree issued on 23 March 1926 set up a series of republican funds independent of the regional offices (Glavsotsstrakhi), to redistribute local resources: (A) local pensions and benefits fund; (B) district healthcare fund; (C) provincial social security fund; (D) provincial medical fund; (E) regional offices' republican fund; $(\mathrm{F})$ republican fund of the People's Commissariat of Health (Narkomzdrav); (G) Tsustrakh fund. Funds A and B comprised employers' contributions, fines and penalties, and capital levies; 5 per cent of receipts were paid into the Chief Administration Fund and 5 per cent into the All-Russian Administration Fund, and a payment was also made into the republican social security fund. The two provincial social security and assistance funds, $\mathrm{C}$ and $\mathrm{D}$, received the residue of local funds, plus fines and grants from the regional office. ${ }^{5 \mathrm{I}}$ In practice, some money did trickle down from the Republican Fund to the local funds, but "this insurance still did not guarantee all claimants enough to live on", despite a rise in the mean value of welfare benefits proportionate to the claimants' cost of living. (In I 922 benefits represented 0.6 per cent of wages, 2 per cent in $1923,3.3$ per cent in 1924,5 per cent in 1925 , 5. I per cent in 1926.$)^{52}$

If the average level of benefits went down it was almost certainly because the cost of disability benefits was going up. In I924-1925 there was a 50 per cent increase in accidents in heavy industry, from 26 per 1,000 workers in the last quarter of 1925 to 44.3 in the last quarter of 1927 . The highest number of accidents was in mining, the lowest in the textile industry. This problem, often blamed on the use of unskilled peasant immigrants, was particularly acute in the Urals, where industrial conditions were at their most primitive. The Economic Council allocated 20 million roubles to health and safety at work, but they were not used either to prevent accidents or to finance social insurance, ${ }^{33}$ owing to a I 7 -million rouble shortfall in contributions paid by firms to Central Administration for $1925 / 1926.54$ The insurance funds' reports show that temporary disability benefits were inadequate, and the available medical care was insufficient to deal with illness in the workforce. The problem of temporary disability, caused by accidents at work or by occupational diseases, can be illustrated from one of the remotest areas, Odessa, whose insurance fund was symptomatic of the chronic deficit afflicting Ukrainian industry. The Odessa fund could not guarantee disability benefits for

5. Baevskii, Praktika sotsial'nogo strakhovaniia, p. I04.

52. Zalebin, Puti i sud'by sotsial'nogo strakhovaniia, p. I04.

53. See E.H. Carr and R.W. Davies, A History of Soviet Russia: Foundations of a Planned Economy 1926-1927, 4 vols (London, I969), vol. I/2, ch. 22, "Social Policies".

54. "Obsuzhdenie Biudzheta Sotsstrakha v Sovete Narodnykh Komissarov i Sovete Truda i Oborony SSSR", Voprosy strakhovaniia, 2 (1928), pp. 3-4; "Pochemu proiskhodit pereboi v RSFSR (beseda s zav. Fond. Otdelom Glavsotsstrakha tov. Khiamialianennom)", Voprosy strakhovaniia, 30 (1928), p. I०. 
metalworkers, almost all of whom suffered from lead poisoning; io per cent of them (out of a total of 523) also suffered from respiratory illnesses or rheumatism.5s Another report, by the Donbass fund, shows that the miners received virtually no healthcare, because the clinics were in a dire state, with a rapid turnover of medical staff, atrocious hygiene, leaking roofs, no heating, and bandages made of torn-up sheeting. ${ }^{56}$ Further search in the archives may show whether the central organizations actually provided any money, or whether local officials wrote begging for funds to help the miners, who in the coming years of breakneck industrialization would see the wellbeing promised by the Revolution recede into a distant dream.

The scantiness of these benefits was also due to the fact that officials did not always spend what money they had in the way prescribed by the reforms. To safeguard the funds earmarked for disability benefit, which executive committees had been channelling into social work or improvements to hospitals, a regulation was issued on 9 August 1926 prohibiting the use of social security funds for any purpose not specified by law. ${ }^{57}$ On I 8 August 1926, a second regulation increased the disability pension to 40 per cent of wages, the same in both town and country. ${ }^{8}$ In the country, the I 3 -rouble benefit paid to disabled peasants was not enough to live on, and so mutual assistance committees and workers' cooperatives were set up and homes for the disabled built; in 1926 they sheltered 21,000 disabled persons. The aim was for these homes to become self-sufficient by engaging in handicrafts and trade..$^{99}$ Despite these attempts to improve the welfare of the disabled, their number, age, sex, and family circumstances were not recorded in the census of 17 December 1926, which therefore lumped together two different social groups, one in receipt of social protection (disabled soldiers) and the other in receipt of social insurance (disabled workers). ${ }^{60} \mathrm{~A}$ decree issued on 9 March 1927 allowed the state to intervene in the financing of pensions paid to 105,000 disabled war

55. "Mozhno li umen'shit' razmer strakhvznosov? (Iz materialov Odesskogo gubstrakha)", Voprosy strakhovaniia, 22 (1924), pp. 8-9.

56. "Obzor pechati (Nedostatki lechebnogo dela na rudnikakh Donbassa)", Voprosy strakhovaniia, 4 (1925), p. I3.

57. B.G., "Mestnye ispolkomy i strakhovie organy. (Vzaimootnosheniia uregulirovanii)", Voprosy strakhovaniia, I9 (1927), p. 7.

58. A. Samsonov, "Postanovlenie SNK RSFSR po uluchsheniiu dela sotsial'nogo obespecheniia”, Voprosy sotsial'nogo obespecheniia, I7-I 8 (I926), pp. I-2. In 1926/1927, 60 per cent of the disabled in urban areas were receiving benefit as against 10 per cent in the countryside, while 30 per cent received no benefits at all: "Kak provodit' pensionirovanie v 26/27 biudzhetnom godu", Voprosy sotsial'nogo obespecheniia, 22 (1926), pp. I-2.

59. Samsonov, "Sostoyanie sotsial'nogo obespecheniia", pp. 4-8.

60. V. Beleliubskii, "Predstoiashchaia perepis' naseleniia i sotsial'noe strakhovanie”, Voprosy strakhovaniia, 6 (1925), pp. 7-8. 
veterans, requiring 25 per cent of local social security budgets to be allocated for this purpose (though the census listed 500,000 disabled persons in the Russian Republic alone). ${ }^{61}$

In comparison with these disabled workers and war veterans, who had defended communism with their blood, the unemployed were considered as second-class claimants. The organizational and social consequences of this can be illustrated from the Moscow and Tula funds. They show implicitly the failure of the central authorities to intervene, and also reveal the survival strategies used by the disabled and unemployed. Between October 1925 and April 1926 the deficit in the Moscow fund rose from Io million to I 4 million roubles, owing to employers' inability to pay and to a doubling of benefits paid to the disabled, the unemployed, widows and the sick (sickness benefits were twice the average for the Russian Soviet Federative Socialist Republic). ${ }^{62}$ The Tula regional fund is particularly interesting: an enquiry into the budget of thirty metalworkers' families from March 1925 to June 1925 compares unemployment benefit, as a source of income, with other family income (wages, sale of possessions, sale of handicrafts, loans). The unemployment benefit could be anything from $\circ$ to 2.24 roubles; other benefits were less erratic (between 3.79 and 3.49 roubles), while temporary disability benefit was between 0.37 and I.5 roubles. Sundry income varied between 6 and 6. I roubles (more in April I4 roubles). More generally, the contribution of social security payments to family income averaged 8.I roubles plus 2.5 roubles for medical expenses. ${ }^{63}$

This enquiry shows that workers still maintained their links with the countryside, but it was the women in particular who made ends meet by working from home on anything from sewing to stock-rearing. ${ }^{64}$ The death of a breadwinner - whether in town or country - put women in a particularly vulnerable position: they might be turned out on to the streets, along with many young people. Although some special settlements were created for vagrants, who were then expected to finance themselves through handicrafts and farm work, this workfare system could not save all members of these unskilled social groups from a life of homelessness. ${ }^{65}$ From 1926 there was a sharp increase in the number of vagrants $(\mathrm{I} 62,8 \mathrm{I} 8$ ), particularly women, along with 300,000 homeless adolescents, sick and

6I. "Poriadok ispol'zovaniia gosbiudzhetnykh sredstv po pensionirovaniiu", Voprosy sotsial'nogo obespecheniia, 8 (1927), pp. I-2.

62. G.I., "Moskva pered krizisom", Voprosy strakhovaniia, 24 (1926), pp. I6-I7.

63. S.L., "Sotsial'noe strakhovanie v biudzhete rabochei sem'i (Tula)", Voprosy sotsial'nogo obespecheniia, I9 (1927), p. 6.

64. W.Z. Goldman, Women, the State and the Revolution: Soviet Family Policy and Social Life, 1917-1936 (Cambridge, 1993), p. I 50.

65. Ibid. 
starving, surviving as best they could by theft and prostitution. ${ }^{66}$ The introduction of the First Five-Year Plan did nothing whatever to improve the living conditions of these poor people.

\section{“DIFFERENTIATION” IN SOCIAL SECURITY ( I 928 - I936)}

The First Five-Year Plan introduced no changes in the financing of social security; no planned, centralized financial organization was created. Welfare benefits tended to atrophy, being steadily replaced by higher wages, better rationing and housing - for skilled workers. The disabled and unemployed were progressively excluded and marginalized; official sources give no hint of the means that could be used to escape the crushing burden of poverty. Before looking closely at the reforms brought in during this period we must look at the five-year social security plan, then at the reorganization of the insurance funds in I93 I, before showing how the management of gradated social security passed from the People's Commissariat of Labour to the Unions in 1933, against the background of the Great Depression and its impact on the USSR. The effects of the Depression have been almost wholly ignored by historians of the Stalinist regime, but in fact they do much to explain the collapse of so many Soviet institutions and the abyss into which Soviet society sank at this crucial juncture of recent history.

The five-year social security plan was not particularly ambitious. It did not seek to generalize social security provision, envisaging an increase of only 2 million claimants over the next five years. On the threshold of the Five-Year Plan, welfare benefits were still very low in proportion to living standards, and they were to be virtually annihilated by inflation over the next few years. The actual intention was to significantly increase benefits to workers, who from 1927 onwards were also entitled to housing, paid for by a 0.5 per cent levy on contributions to the insurance funds. ${ }^{67}$ In $1927 /$ I 928 there were 9,700,000 workers in receipt of various welfare benefits ( 87 per cent of the total workforce). The average income was 63.97 roubles, whereas welfare payments comprised average daily benefits of 2.54 roubles for disability, 2I.4I for each dependent child, 5.47 maternity allowance, I 8.58 death benefit, 2 I.57 for the disability or death of the breadwinner one-third of an insured worker's average monthly wage. As for the unemployed, only half of them $(657,000)$ received benefits, which were between 7 and 27 roubles depending on location; one-quarter of them also

66. In 1923 the majority of vagrants were women (25,I4I out of 36,976): A.A. Gertsenzon, "Nishchenstvo i bor'ba s nim v usloviyakh perekhodnogo perioda", in E.K. Krasnushkina et al. (eds), Nishchenstvo i besprizornost' (Moscow, 1929), pp. 6-56, 22-23, 25, and I40-I4I.

67. See Carr and Davies, History of Soviet Russia: Foundations of a Planned Economy, vol. I/2, ch. 22(a), "Housing". 
received payments for each family member, amounting to between is and 35 per cent of wages. ${ }^{68}$

By the end of the Plan, however, there seemed some prospect of an increase in benefits, since wages had risen 7I per cent above their prewar level, and the number of insured persons had increased by just over two million - one million disabled persons and widows and I,400,000 registered unemployed (I I per cent of the workforce, including unskilled workers, bricklayers, canteen and shop workers). ${ }^{69}$ But this was one of the delusive promises, based on fantasy figures, which abound in the literature of the First Five-Year Plan. By 1928, V.V. Shmidt had realized that the Central Administrations were in crisis owing to the deficits of previous years, and declared that the restoration of normal contribution rates for firms not in deficit would not solve the problem: Central Administration needed not a billion roubles, but at least $\mathrm{I} 3$ billion or even more ${ }^{70} \mathrm{But}$, in spite of the resulting cutbacks in expenditure and welfare payments, on I 8 May 1929 old-age pensions were introduced for the first time, and paid to 70,000 individuals.

Shmidt's speech foreshadowed further cuts in welfare spending and numbers of beneficiaries, especially as the country's planned economic development had ground to a halt, probably owing to the worldwide economic crisis. Although the effects of this crisis have yet to be fully studied, comments by a leading contemporary economist, E. Varga, hint at the profound emotional impact it had in the USSR. In 1929 he commented that the world economy had fallen prey to a new phase of imperialism which might lead to war and an attempt to "strangle the USSR"..$^{71}$ It is very likely that the crisis had begun to bite in Russia by the end of that year. A number of regulations issued in 1929 seek to justify a discriminatory suspension of unemployment benefit for any worker who did not join a union and live in an urban area, on the grounds that some of the unemployed still had links with the countryside. As for disability benefit, the new regulations further extended the qualifying period (average length of employment) from between one and eight years to twelve for disabled workers, sixteen for white-collar workers and twenty-four for persons deprived of civil rights. ${ }^{72}$ Maternity benefits were also restricted, providing some sort of incentive to take on female factory workers. Attempts to justify these restrictions on ideological grounds generated a new kind of discourse relating to the chistota ("purity") of the social security laws, which was designed to exclude workers of nonproletarian origin who were

68. Zalebin, Puti i sud'by sotsial'nogo strakhovaniia, pp. 95-97.

69. Ibid., p. 91.

70. "Obsuzhdenie Biudzheta Sotsstrakha v SNK i STO SSSR", Voprosy strakhovaniia, 2 (1928),

pp. 3-4; "Pochemu proiskhodit pereboi v RSFSR", p. го.

7I. E. Varga, Problemy mirovogo khoziaistva i mirovoi politiki (Moscow, 1929), p. 7 I.

72. "Za ekonomiiu strakhovykh sredstv", Voprosy strakhovaniia, I3 (1928), p. I. 
seen as "alien elements": "The social security law must be a tool of the proletarian class; it must serve the interests of the proletariat and be directed against our enemies." 73 On 25 November 1929 a regulation was issued initiating a "purge" of "alien elements" among the disabled and unemployed - already penalized if they lived in rural areas. ${ }^{74} \mathrm{~A}$ decree issued on I 3 February 1930 imposed further limits on disability and oldage pensions for urban dwellers deprived of voting rights, workers who had lost their jobs because they had been involved with Tsarist institutions or taken part in counter-revolutionary activities, and victims of purges. ${ }^{75}$

All this discrimination had the effect of marginalizing individuals, who were then probably deported along with peasants opposed to the collectivization of the countryside. ${ }^{76}$ Permanent suspension of unemployment benefit was licensed by a directive from the Central Committee of the Communist Party on 20 October 1929, which forced unskilled peasants, adolescents, and women to work in industry. ${ }^{77}$ But this, again, was merely a political gesture which had little effect in practice: unskilled labourers did pour into the factories over these years, but they were worse paid and worse fed than other workers, and were periodically laid off, as had happened to peasants doing seasonal work throughout the i920s. The headlong expansion of heavy industry reduced the number of women workers, or relegated them to traditionally "female" industries such as electricity, mining and fuel, metallurgy and machinery, textiles, sewing, clothing, rubber, and matches. ${ }^{7}$ Official figures also reveal that 4 million adolescents were illiterate and so without any professional training. In I929-1930, of 315,000 I I to I 5-year-olds, only 93,000 (28 per cent) went to school. The others were doing casual work, or hanging about on the streets with other abandoned children.79

Official sources from this period are strangely silent about social practice by both central and local institutions, but they do include budgets - which frequently do not add up. But, bearing in mind a regulation which ordered that the 75 million roubles from the insurance fund that were deposited with the State Bank in 1930 should be used as (forced) "loans for the building of socialism", 80 we can guess that they were diverted to the

73. "Sotsstrakh v usloviiakh klassovoi bor'by", Voprosy strakhovaniia, 46 (I929), pp. I-2.

74. V.S., "Izmeneniia v zakonakh i zadachi strakhkass", Voprosy strakhovaniia, 48 (I929), p. I; "Profsoiuzy i sotsstrakh (K Plenumu VTsSPS)", Voprosy strakhovaniia, 48 (I929), p. 2.

75. Iakushev, Gosudarstvennoe strakhovanie v Rossii, pp. 71-76.

76. S. Fitzpatrick, Stalin's Peasants: Resistance and Survival in the Russian Village after Collectivization (Oxford, 1994), pp. 53-55.

77. "Protiv bezrabotnitsy. Za proletarskuiu revoliutsiiu", Voprosy strakhovaniia, 7 (1930), pp. I-2.

78. Goldman, Women, the State and the Revolution, pp. 310-3 12.

79. V. Bashkerevich, "O chetyrekh millionakh negramotnikh rebjat", Vozhatii, 22 (1930), pp. 9-II.

80. "Za tverduiu financovuiu distsiplinu", Voprosy strakhovaniia, s (I930), p. I. 
construction of new industrial complexes such as Magnitogorsk - or to new housing. However that may be, when the funds were reformed yet again in 193 I there was no mention of transferring central insurance funds, because at the beginning of that year (decrees of I4 January and 20 March) a new productivity criterion had been imposed on industrial firms: no loans would be forthcoming unless the production plan had been fulfilled. This change to industrial finance also affected social protection. On 27 January I93 I the Central Committee of the Trade Unions set up local industrial funds (otraslevye kassy) in order to reorganize social protection sector by sector. ${ }^{81}$ Each fund set up "payment points" (vyplatniie punkty) to deal with all forms of social security for blue- and white-collar workers in each enterprise, and monitor the contributions paid by each firm to the local fund. The latter was no longer seen as a "common pot" from which funds would be distributed locally. Instead, the industrial funds, which were managed by trade-union officials under orders to combat mobility and promote "shock work" (udarnichestvo), turned into a mechanism for favouring productive workers and excluding any who flouted the labour laws. ${ }^{82}$ Because some officials had paid benefits to workers in other, less productive enterprises in the same branch of industry, the unions proposed that each enterprise should finance its own fund, which would then distribute benefits only within that enterprise. ${ }^{83}$

This change of direction is not unconnected with a conference of industrialists on 23 June I93 I, at which Stalin finally rejected the principle of wage egalitarianism (uravnilovka) because, he said, socialist society needed to "differentiate between skilled and unskilled labour, heavy and light work". ${ }^{84}$ This speech, probably inspired by anxiety over a recent 10 per cent drop in exports (which now covered only 67 per cent of the cost of imported machinery required for the purposes of industrialization), ${ }^{85}$ was aimed at increasing workers' productiveness. Piece rates were introduced in I93 I, and workers in heavy industry, particularly the "shock workers", received better rations. ${ }^{86}$ They were the only ones able to keep up with inflation and the reduction of rations which followed the localization of

8I. V., "V Plenum VTsSPS. Za korennuiu perestroiku raboty profsoiuzov i sotsstrakha", Voprosy strakhovaniia, 32-33 (1931), pp. 7-8.

82. M., "V pomoshch' vyplatnomu punktu na predpriiatii", Voprosy strakhovaniia, I I (I93 I), p. 7.

83. G. K-ov, "Sostrakh na perestroike", Voprosy strakhovaniia, I 2 (I93 I), pp. 4-6.

84. A. S. Krasnopol'skii, Osnovnye printsipy sovetskogo gosudarstvennogo sotsial'nogo strakhovaniia (Moscow, I95 I), p. I35.

85. R.W. Davies, Crisis and Progress in the Soviet Economy, I93 I-I933 (Basingstoke, I996), pp. II $8-$ I 2 I.

86. O. Khlevnyuk and R.W. Davies, "The End of Rationing in the Soviet Union, 1934-1935", Europe-Asia Studies, 5I (1999), pp. 557-609, 559-560. 
resource management, especially as they were also entitled to jump the housing queue. ${ }^{87}$

The circumstances of other workers deteriorated steadily, especially towards 1932. Two examples, from Magnitogorsk and the Donbass mines, will show this sharp deterioration in the health and living conditions of workers who were poor enough to start with: ${ }^{88}$

At Magnitogorsk, where the population rose from between 55,000 and 60,000 to 175,000 in the course of 1931, the number of meals per worker declined. So did the number of medical visits, in spite of outbreaks of illness owing to "confined conditions in barracks, dirt, insanitary conditions in the area around the barracks, and filthy toilets". Absenteeism without due cause increased. This reflected a general deterioration in labour discipline. [...] The influx of unskilled workers into the labour force, the poor conditions, and the production difficulties already described, resulted in a decline, or at best a stagnation, in labour productivity. Even according to the official record, daily output per manual worker declined by 4 to 5 per cent in the chemical, coal, and iron and steel industries. ${ }^{89}$

The miners in the Donbass not only had no access to social services or sanitation, but lived in wretched hovels and suffered from working conditions that were completely unsafe: "If in 1906-1913, 2.6 deaths for every 1,000 miners were recorded in the Donbass, the corresponding figures were 2.9, 2.84, and 2.84 for 1929, I934, and I935 respectively." 90 These examples are completely typical of most workers' living conditions, which were exacerbated from 1932 onwards by repressive labour laws intended to tighten factory discipline..$^{9 \mathrm{I}}$

I 932 was probably the crisis year for welfare and was the hardest for Soviet labourers, who had to work harder to increase industrial production by 14 per cent..$^{22}$ It would be interesting to compare memories of 1932 among various types of workers worldwide. We already know that iron and steel workers in the Ruhr looked to their government to find a solution, whereas Americans were more distrustful - so much so that their

87. J.-P. Depretto, Les ouvriers en URSS, 1928-194I (Paris, 1997), p. 256.

88. S.G. Wheatcroft, "The Great Leap Upwards: Anthropometric Data and Indicators of Crises and Secular Change in Soviet Welfare Levels, I880-I960", Slavic Review, 58 (1999), pp. 27-60, 28, 3 I.

89. Davies, Crisis and Progress, pp. I09-i Io.

90. H. Kuromiya, "Workers under Stalin: The Case of the Donbass", in M. Hildermeier (ed.), Stalinismus vor dem Zweiten Weltkrieg: Nene Wege der Forschung [Stalinism Before the Second World War: New Avenues of Research] (Munich, 1998), pp. 79-97, 88.

91. A. Andrle, "How Backward Workers Became Soviet: Industrialization of Labour and the Politics of Efficiency under the Second Five-Year Plan, 1933-1937", Social History, io (1985), pp. I47-169.

92. Davies, Crisis and Progress, pp. $458-459$. 
experiences had a decisive impact on their family life. ${ }^{93}$ But did they pay any attention to the new value of "hard work" as a way of escaping social deprivation and regaining some sort of comfort? Soviet propaganda embodied this new value in the figure of the "new man", confident in his own strength. The propaganda was swallowed by Soviet skilled workers, who were quick to realize the material advantages that the new regime was bringing them to ensure they eluded the snares of world capitalism. But these "privileges" actually depended on the exploitation of peasants in the kolkhozy, who had to supply grain in exchange for 50 per cent payment in kind, and whose scope for action was reduced to survival strategies - the cultivation of sovchozy near factories and schools, barter, or theft. ${ }^{94}$

One way to measure the impact of the Great Depression on the USSR is to compare imports of necessary machinery for industrialization with the two most important exports, grain and oil. This impact, combined with other new elements such as Stalin's "great peasant war",95 and the obsessive fear of conspiracies by saboteurs at home and of attack from outside (by Japan), led to the growth in the production of war materials, the waves of repression in I93 I-I933, and the apocalyptic mood evident at that time. ${ }^{96}$ It was in that political climate that, on Io September 1933, control of social security was transferred to the trade unions, who could now "differentiate" even further by increasing the wages of shock workers and getting rid of any who were "alien" and/or "unproductive". ${ }^{97}$ Welfare benefits were replaced, once and for all, by better wages, along with extra rations and housing - the goal of most workers, more and more of whom

93. L. Cohen, Making a New Deal: Industrial Workers in Chicago, 1919-1939 (Cambridge, 1990), pp. 2 I 3-249; A. Lüdtke, Les ouvriers dans l'Allemagne du XXième siècle. Le quotidien des dictatures (Paris, 2000), pp. I53-I57.

94. In some parts of the USSR the population was no longer receiving the prescribed ration and was suffering from hunger even before the famine that struck the Ukraine in summer 1932. See E.A. Osokina, Ierarkhiia potrebleniia. O zhizni liudei v usloviiakh stalinskogo snabzheniia, 1928-1935 gg. (Moscow, 1993), pp. 17-43, 30-3 I, 106-107.

95. A. Graziosi, Velikaia Krest'ianskaia voina v SSSR. Bol'sheviki i krest'iane, I9I7-I933 (Moscow, 200I), pp. 45-68.

96. See G. Rittersporn, "The Omnipresent Conspiracy: On Soviet Imagery of Politics and Social Relations in the I930s", in J. Arch Getty and R. Manning (eds), Stalinist Terror: New Perspectives (Cambridge, 1993), pp. 99-I I 5; Davies, Crisis and Progress, pp. 459-460; N. Werth, "Rumeurs défaitistes et apocalyptiques dans l'URSS des années 1920 et 1930", Vingtième Siècle. Revue d'Histoire, 7I (200I), pp. 25-35. A study of the impact of the Depression on the USSR might also resolve the argument between H. Haumann and M. Hildermeier over the USSR's "flight forwards" at the time of the First Five-Year Plan: see Haumann, "Jugend und Gewalt in Sowjetrussland zwischen Oktoberrrevolution und Stalinismus im lebensweltlichen Zusammenhang", in C. Kuhr-Korolev et al. (eds), Sowjetjugend 1917-194I. Generation zwischen Revolution und Resignation (Essen, 200I), pp. 25-6I, 53.

97. V. Roik, "Rossiiskii opyt. Strakhovanie ot neshchastnykh sluchaev na proizvodstve proshlo v Rossii te zhe etapy, chto na Zapade”, Okhrana truda i sotsial'noe strakhovanie, pp. 22-24; see also P. Hagenloh, "'Socially Harmful Elements' and the Great Terror", in Fitzpatrick, Stalinism: New Directions, pp. 286-3 I 2. 
were joining the Stakhanovist movement. On 6 July 1936 it was decreed that the state social security budget should be split in two: half would be spent on new housing, the other would be spent by the Party's Central Committee according to the needs of trade-union members - which would certainly mean preferential treatment for the most productive workers. ${ }^{9}$

I 936 brought some improvement in material conditions for a population which had believed in the promises of the Revolution, ${ }^{99}$ but this improvement did not lead to any slackening in the repressive labour laws, nor in the purging of managers who were held responsible for accidents at work in the following year. ${ }^{100}$ Very little now remained of the social security promised by the Revolution to improve the lives of so many millions of people. The Party had abandoned its welfare system in an attempt to insulate the USSR from the effects of the Great Depression. It did not succeed, and the consequences of that Depression were to precipitate Europe into a world of new dictatorships and mass exterminations.

\section{CONCLUSIONS}

Our study of social welfare in the I920s and I930s has shown that the new Soviet government was not trying to develop a new model of communist solidarity based on equal treatment for all social groups. On the contrary, it set out to discriminate between workers and peasants, the skilled and the unskilled, the trade-union members and the non-members, the more productive and the less productive. Hence our study opens up new perspectives and suggests new approaches to a series of crucial questions. How did the Soviet government and the Party cope with social problems? Why did people knuckle under to the regime, and why did the economy collapse in the early i930s? How did European governments differ in their approach to social problems? In particular, how did they deal with unemployment, the worst problem of all during the Depression, and one which attracted intense interest in the international working-class movement?

There can be no doubt that our understanding of how welfare systems worked will be greatly improved by microhistorical research into the insurance funds. We must look at the actions of individuals, groups, social strata, and social classes and put their experiences in context, as is done by anthropologists of family life, who set out to examine how emotions and

98. Iakushev, Gosudarstvennoe strakhovanie v Rossii, p. 84.

99. S. Davies, Popular Opinion in Stalin's Russia: Terror, Propaganda and Dissent, I934-194I (Cambridge, I997), pp. 23-25.

ıо0. Iakushev, Gosudarstvennoe strakhovanie v Rossii, pp. 87-91; P.K. Popov, "O rabote profsoiuzov po okhrane truda", Okhrana truda, 2-3 (1928), pp. $22-27$. 
material interests interact and finally merge. ${ }^{\text {I0I }}$ Here is an interpretative model which can be used when trawling the archives for applications for welfare payments (pensions, benefits, healthcare) from various social groups. This may show how far "political commitment" to communism and the "material interests" of social security interacted in the daily life of millions of people, and how people reacted when they lost their jobs and were inexorably deprived of all rights and forced to fall back on survival strategies, both legal and illegal. ${ }^{102}$ By examining how far welfare benefits and/or preferential treatment for shock workers and Stakhanovists ${ }^{103}$ increased acceptance of the new regime, we can reopen the debate between the totalitarianists and the revisionists. ${ }^{104} \mathrm{We}$ can also begin to understand how the regime nursed the hopes and expectations of various social groups, while keeping them constantly beneath the Damoclean swords of global unemployment and a life of deprivation such as was endured by abandoned and delinquent youngsters who had grown up to a life of loitering and thieving on the streets. ${ }^{\text {Ios }}$

I would argue that the Great Depression forced up unemployment in the USSR as in other countries, although official propaganda concealed the fact that "alien elements" had been removed by purging various types of workers. For millions of individuals, losing their jobs was the first step on a road that led inexorably to debt, theft, and incarceration in the gulags. In the I 920 s they had constituted a social problem; now they were a criminal one. Whereas the Nazis based their exclusion of various social groups, including the unemployed, on racist ideology, the Communist Party developed an ideological discourse which progressively transferred social problems from the social sphere to the sphere of criminality and repression. ${ }^{106}$

Soviet propaganda gave a very different impression of the government's planned solution to the unemployment problem. It is interesting in this

Iог. H. Medick and D. Sabean (eds), Emotionen und materielle Interessen. Sozial-anthropologische und historische Beiträge zur Familienforschung (Göttingen, I984), p. I I.

102. D. Beyrau, "GULAG - die Lager und das Sowjetsystem", Sozialwissenschaftliche Informationen, 29 (2000), pp. I66-176.

103. R. Maier, Die Stachanov Bewegung, 1935-1938. Der Stachanowismus als tragendes und verschärfendes Moment der Stalinisierung der sowjetischen Gesellschaft (Stuttgart, 1990), pp. I I 5 -I 46.

I04. S. Kotkin, Magnetic Mountain: Stalinism as Civilization (Berkeley, CA, I995); J. Hellbeck, "Rethinking the Stalinist Subject: Stephen Kotkin's Magnetic Mountain and the State of Soviet Historical Studies”, Jabrbücher für die Geschichte Osteuropas, 44 (1996), pp. 456-463; S. Kotkin, "199I and the Russian Revolution: Sources, Conceptual Categories, Analytical Frameworks", Journal of Modern History, 70 (1998), pp. 384-425. See also B. Studer, "Totalitarisme et stalinisme", in M. Dreyfus, Le siècle des Communismes (Paris, 2000), pp. 27-46, 34 .

I05. Caroli, La génération des "bommes nouveaux".

ı06. G.A. Ritter, "La sécurité sociale en Allemagne de Bismarck à nos jours", in Un siècle de protection sociale en Europe, pp. 8-17. 
context to look at the visit paid to the USSR by two of the leading lights of the international working-class movement, Beatrice and Sidney Webb, in 1932. They were impressed not only by its "miraculous" economic development, but also by the fact that the USSR appeared to have solved the unemployment problem. ${ }^{107}$ They devoted two years to composing their vast work Soviet Communism: A New Civilization? (1936), in which they hailed the dawn of this new "civilization" based on social protection, culture, and political education. ${ }^{108}$ Asylums, hospitals, housing, interestfree loans, efficient emergency services, and in particular the most advanced women's rights legislation in the world: all this was grounds for talking in terms of a new civilization, which ought to serve as a model for degenerate capitalism. ${ }^{109}$

It is surprising to note that while preparing this monumental work in summer $1932,{ }^{110}$ the Webbs discussed their journey with Sir William Beveridge (1879-1963), stressing that the USSR, thanks to careful planning, seemed to have solved the unemployment problem which had baffled the capitalist countries, where there were I 3 million unemployed in 1933. Although Beveridge was not convinced that planning could prevent unemployment, ${ }^{\text {II }}$ his biographer, Jose Harris, has argued that he was probably strongly influenced by the Webbs when drafting his social welfare proposals in 1942, which in turn influenced the social policies of many European countries after the Second World War.

His conception of how to cure unemployment in 1942 was, in many respects, very similar to that advanced by the Webbs in Soviet Communism. [...] It was a cure based on state control of production and on detailed planning of the deployment of labour rather than on monetary and fiscal regulation of consumer demand. Where Beveridge chiefly differed from the Webbs was in his belief that full employment could be maintained without massive coercion. ${ }^{112}$

The Beveridge report, published in 1942 , set out a long series of proposals for a "national health service, a family allowance, full employment and a comprehensive system of social insurance designed to cover the

107. Beatrice and Sidney Webb also wrote The Decay of Capitalist Civilization (New York, I923).

I08. After the First World War, Sidney Webb had suggested the creation of a "social parliament" to manage all issues relating to the economy and to social, financial or fiscal policy. See Ritter, Sozialversicherung, p. 82; idem, Der Sozialstaat. Entstehung und Entwicklung im internationalen Vergleich (Munich, I989), p. I25.

109. See B. and S. Webb, Soviet Communism: A New Civilisation, 2 vols (London, 1937), vol. 2, ch. Iо, "The Re-making of Man", pp. 805-943.

I 10. See J. Harris, William Beveridge: A Biography (Oxford, I977), ch. I3, "Liberalism, Socialism and Economic Planning", pp. 3 I I -377.

I I I. Ibid., p. 326.

I I 2. Ibid., p. 430. 
whole community". "I3 This "Beveridge Plan" influenced not only the Belgian and Dutch governments exiled in London, but also the Allied Control Council (1946), which introduced a new approach in social security. ${ }^{\mathrm{II}} 4$

What is really astonishing, however, is not just that Beveridge was influenced by the Webbs' passionate devotion to communism, but rather that the influence may have been reciprocal. After the Second World War the Soviet Union introduced a social security system which included an immense programme to extend welfare to both productive and unproductive social groups and so win the support of a society emerging from Stalinism. ${ }^{\text {II }}$

Translation: Rosemary Williams

I 1 3. Ibid., p. 419; Social Insurance and Allied Service - Report by Sir William Beveridge (New York, I942).

I 14. "Instead of different social insurance branches a uniform organization was planned, the coverage was supposed to be extended to nearly all employees and benefits were supposed to be financed by an integrated contribution rate for all branches (except for the obligatory accident insurance). The influence of the Beveridge Report is obvious. One aim seems to be to limit pension expenditure. In 1946, in Berlin and early in 1947 in the part of Germany occupied by the Soviets this approach was realized. Meanwhile, the British Labour government had introduced a redefinition of social security along some [of the] lines of the Beveridge Report by integrating the different social insurance branches and extending coverage to the total population": W. Schmähl, "The Flat-rate Public Pension in the German Social Policy Debate from the Early Nineteenth to the Late Twentieth Century", paper presented at the conference "Social Security 50 Years after Beveridge”, York, 27-30 September I992, p. 9. See also Ritter, Der Sozialstaat, pp. I46-I 49. I I 5. N.E. Tikhonova and O.I. Shkaratan, "Rossiiskaia sotsial'naia politika: vybor bez alternativy?”, Sotsiologicheskie Issledovaniia, 3 (200I), pp. 21-32, 23. 